\title{
South China, East Vietnam or West Philippine? Comparative Framing Analysis of Regional News Coverage of Southeast Asian Sea Disputes
}

\author{
Bradley C. Freeman ${ }^{1, *}$ \\ ${ }^{1}$ Associate Professor of Communication \& Information Studies, Mohammed bin Rashid School for \\ Communication, American University in Dubai, United Arab Emirates
}

\begin{abstract}
For years, the world paid scant attention to the sporadic skirmishes and sovereignty squabbles in what is known by many as the South China Sea. However, in the past few years, there have been several noteworthy happenings that have drawn the attention of media outlets, including a Chinese oil rig placement near Vietnam, a Philippineinternational court case, a U.S.-ASEAN summit, and Chinese reclamation projects. Many of the countries involved are members of the regional grouping known as ASEAN (Association of Southeast Asian Nations). This study examined Asean's English-language press, looking at the amount, patterns, and tone of coverage given to regional maritime disputes. Results indicate that use of the term 'South China Sea' prevails in all countries except Vietnam. The Asean newspapers have devoted a consistent and substantial amount of space to covering the topic. Indonesia's Jakarta Post tended to use neutral or positive language when mentioning Asean and the US, while China saw more negative associations in the coverage. Further research is suggested, taking into account mass communication theories and perspectives.
\end{abstract}

\section{Introduction}

To any casual observer of world events and international relations, it would have been difficult in the past few years to avoid news items mentioning disputes related to what is often referred to as the South China Sea region. While the issues involved have existed for many decades, and researchers have raised concerns about potential conflict previously [1, $2,3]$ international news media have tended to cover the mainly territorial disputes through the lens of each incidences' newsworthiness. While news items certainly exist going back many years, the recent increase in the amount and kinds of coverage clearly signals a change in the situation.

Rival countries have argued for years over strategic reefs and atolls in the disputed waters of the South China Sea, a marginal water body that is part of the Pacific Ocean,

* Corresponding author: bfreeman@aud.edu 
covering an area from the Malacca Straits to the Strait of Taiwan. By now, and due in part to the increased news coverage, members of the international community are more familiar with the issues at stake in this affair. Notably, media audiences have come to know about China's "9-dash line," several intermittent dotted lines on maps that demarcate the area where China claims sovereignty. Several countries have overlapping claims to the same area, namely Vietnam, the Philippines, Brunei, Malaysia, Taiwan, and Indonesia. The United States has also become involved in the matter based on the issue of safety of maritime trade routes, its historical presence, as well its alliances with other parties and countries. Other countries have also had a say based on international relations, including Japan, Cambodia, India, and more notably, the regional grouping of countries known as the Association of Southeast Asian Nations (henceforth, Asean).

Countries use many different means to address disputes in an attempt to resolve them. Diplomatic channels, legal cases, and economic means are typically brought to bear on the issue, with military action likely only preferred as a last resort. Recently, China has become more assertive regarding its claims, ramping up island-reclamation and increasing naval patrols. These activities have been met with various responses; increased media attention has followed. For example, a front-page banner headline on February 27, 2016, in The Manila Times declared "China taking de facto Sea control" [4]. In 2013, the Philippines requested that an international tribunal in The Hague hear its arguments against China's activities. At a "U.S. - Asean Summit" the name "South China Sea" was never used in a joint statement - the "Sunnylands Declaration" calling for "respect of each nation's sovereignty and for international law" [5]. In July 2016, the court ruled for the Philippines; a few months later, Philippine President Duterte raised the issue with a Chinese delegation; at the same time, President Obama called the ruling 'binding' [6].

In the information age, countries are aware that how an event plays out in the media can have an effect on awareness, attitudes, and policies. While it may not always be the case, media coverage can create certain frames or perceptions and thus play a role in how governments react and respond. Indeed, Kaplan suggested as much when he wrote that the Philippines, for example, might be "better off employing restraint and an appeal to world opinion" in their disagreement with China [7]. Thus, for the current case, there are (in a way) two "courts" involved: the international tribunal (a matter of law and international relations), and the so-called court of public opinion (a matter of the media and mass communication researchers). The former is an institution in the Netherlands; the latter is an imagined community made up of domestic and international media audiences. This study examines the way that the dispute has been covered and portrayed in Asean's newspapers and discusses what it may mean for the countries concerned, as well as the global community.

\section{Literature Review}

The literature on this topic is vast and comes from several disciplines. Researchers in international relations, military studies, diplomacy, history, international law, geography, Asian studies, and others, have all written about South China Sea disputes. Several prominent books have been published in this area [7, 8].

There is not so much in the way of mass communication studies that have taken on this subject. As this study deals with news coverage and country imaging, several mass communication theories might be applied, and would include agenda-setting (second level), priming, and media framing $[9,10,11,12]$. These theories hardly need an introduction. Over the past several years, they have been used numerous times in many studies [13]. Framing, in particular, implies that news articles can influence the way readers perceive an issue based on the way that the information is presented [14]. In a way, it is the kind of spin 
that a media outlet (or individual journalist) may give (knowingly or unknowingly) to a piece of information - highlighting some aspects, and downplaying other attributes. There are many different influences in the creation of media content and on the end product of news [15]. In cases where the government has an influence (either directly or indirectly), we expect that foreign policy would play a role in the types and kinds of frames that are ultimately written into newspaper articles. In this regard, Reese correctly advised that "framing suggests more intentionality on the part of the framer and relates more explicitly to political strategy" [16].

Studies referencing these theories have taken different approaches and utilized varied methodologies in an attempt to deconstruct and define the phenomena surrounding the subject matter of media coverage and national imaging as formed or supported via mass media. Investigations of the media coverage of individual nations and business companies are more common than on collective regional country groupings [17, 18]. Some public relations studies have also tested whether hiring such counsel alters coverage in any significant way $[19,20]$. Wang wrote that "one of the reliable indicators of a nation's reputation is the opinion of the given nation as expressed by foreign publics" [21]. Brewer, Graf, and Wilnat acknowledged that people depend on the media to gather information about international affairs, and, therefore, the media play a significant role in shaping "mass perceptions" of other nations [22]. These images come in many different forms, from television and press reports, travel features in newspapers, talk radio discussions, and foreign films, to brief, seemingly innocuous comments about a country in a prime time television drama series -- ala Desperate Housewives and the Philippines [23]. Each item represents an attribute of a state, all of which collectively inform audiences what to think and how to think about foreign lands; borrowing from Lippmann it allows for the basic pictures of a country to be shaped in Americans' heads [24].

In examining the literature to date, a clearer picture is forming as to which items will best determine or predict news coverage and the frame of one country in another, given the specific circumstances (i.e., which country and what type of media outlet) and also how this might be affected by or even what effect this may have on policy decisions or other activities [25]. For the present study the frame categories identified by Valkenburg and Semetko [26] are utilized; they are, conflict, human interest, economic impact, morality, and responsibility. Based on previous literature, and given the specifics of the South China Sea disputes, the following research questions are posited:

RQ1: What geographic term is preferred in the Asean print media when it comes to reporting on the marginal sea area that many of its member countries surround? What's in a name? As those working for Google Maps will likely tell you "a lot." There are many areas in the world over which map makers must tread carefully [27]. Use of the name "South China Sea" is one such area of contention [28]. Although a recent Malaysian newspaper suggested that the body of water be renamed as the Southeast Asia Sea, most of the world refers to it by one of three titles: South China Sea, East Sea, and West Philippine Sea. A cursory search revealed that "South China Sea" is clearly the dominant term found in the English-language global press; will that be true for Asean's newspapers?

RQ2: What are the coverage patterns like for Asean newspapers regarding South China Sea disputes? Put simply, how important is this issue to these six countries? The expectation is that newspaper coverage increases as newsworthiness increases. Thus, how many articles have been written in the six countries selected print media outlets during the past five years? This research question is interested in the numbers involved, with the understanding that amount of coverage provides one vantage point towards understanding the situation. 
RQ3: What are the dominant thematic frames uncovered in The Jakarta Post's coverage when it comes to the sea disputes? Several possible frames might be present in the stories. Although arguable, prevailing thought has been that Indonesia had reached a level of bilateral understanding with China concerning South China Sea issues. However, with the fishing boat incidences of 2016, there seemed to be a slight shift in the situation.

RQ4: How does The Jakarta Post's coverage depicts the three principal actors of China, Asean, and the United States? An article in The Yomiuri Shimbun (Japan) stated that China viewed the United States "as an "extra-regional state" in the South China Sea" and refused to accept U.S. intervention in the region [29]. Yet, the same article reported on the US-ASEAN summit and indicated a strengthening of ties between the U.S. and Asean over this matter. Does The Jakarta Post's coverage tends to agree with this position? There is an expectation that it does.

\section{Method}

This study is based on a content analysis of press coverage of newspapers in six of the ten ASEAN member countries: The Philippines - The Manila Bulletin, Vietnam - Vietnam News Agency Bulletin, Malaysia - New Straits Times, Indonesia - The Jakarta Post, Singapore - The Straits Times, and Thailand - Bangkok Post. The newspapers are known and valued in their respective media markets. The purpose of the analysis is largely descriptive in nature, to identify what the reports say, and how this may reflect countries' positions.

The study involved two distinct phases. In the first phase, all six newspapers were examined (2011-2016) to address research questions 1 and 2. In the second phase, relevant articles were reviewed in Indonesia's Jakarta Post (2015-2016) to address research questions 3 and 4. It is anticipated that the corpus of articles will undergo coding - and this represents the next step in this research project. A manual content analysis approach was used to examine coverage based on several key variables. Searches using the Factiva database were carried out using different keywords "South China Sea," "East Sea," and "West Philippine Sea." To investigate coverage of 'Asean' and 'United States' involvement, relevant terms were added and searched within the overall corpus of articles during the second phase which again selected articles only from Indonesia's Jakarta Post. In this phase, 135 articles were initially collected, however after the filtering process, 52 articles were determined to be most relevant and thus underwent the reading and coding process.

The unit of analysis is the article; the recording unit is at the sentence assertion level. Assertions within each article were identified and coded on several levels. For the current conference paper, and due to space and time limitations, only two variables are assessed and are reported here: [1] Dominant Frame - conflict, human interest, economic impact, morality, and responsibility (as used in Valkenburg \& Semetko, 2000). And, [2] Valence (e.g., tone of coverage towards three principal actors): positive, neutral, negative -dictionary of words as suggested by previous research [30, 31, 32].

\section{Results and findings}

The first phase of the search was meant to uncover which geographical term was preferred in Asean newspapers. Similar to global realities, the term "South China Sea" was the term receiving the most use in Asean English-language newspapers, Figure 1. The exceptions are found in the newspapers of Vietnam and the Philippines, where we see greater use of the 
terms "East Sea" and "West Philippine Sea" respectively. Yet, in the case of the Philippines, the term "South China Sea" is still seen more often than "West Philippine.

Sea." In Vietnam, "East Sea" dominates, and the term "West Philippine Sea" is never used at all. Thus in answering RQ1, the results indicate that "South China Sea" is the preferred term outside of Vietnam and to a lesser extent the Philippines.

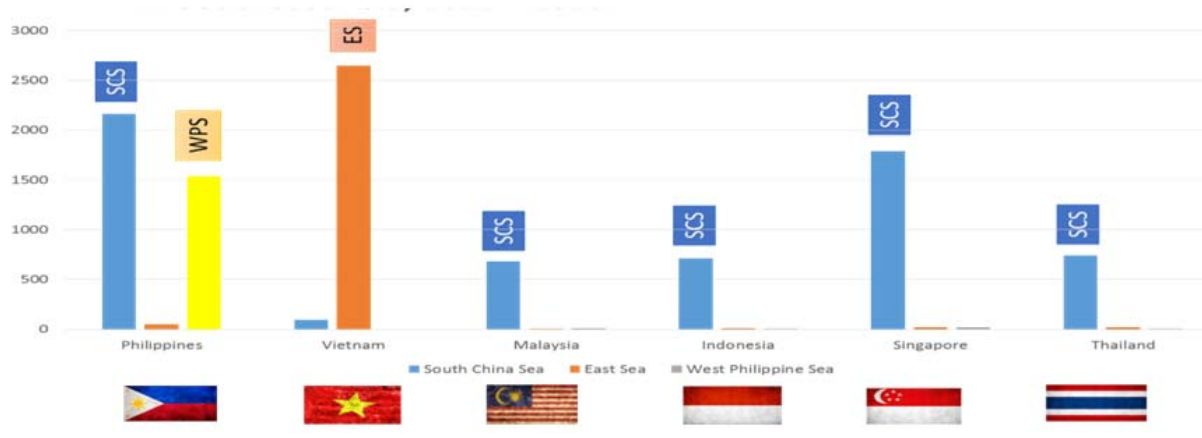

Fig. 1 Preferred geographic term for the main body of water in S.E. Asia, 2011-2016

Figure 2. What we can see are some spikes in coverage, for example, Vietnam's coverage went up in 2014 - and this would be expected due to the issue of a contested oil rig in the waters off of Vietnam's coast (i.e., Hải Dương - 981; [33]). Also noticeable is the large number of articles in the Singapore paper, The Straits Times. One might suggest that only using one newspaper per country might not show the coverage effectively, however, when we added second news sources to the mix, we saw that the coverage was similar to other papers. Thus, focusing on one newspaper from each country was sufficient for the purposes of the study.

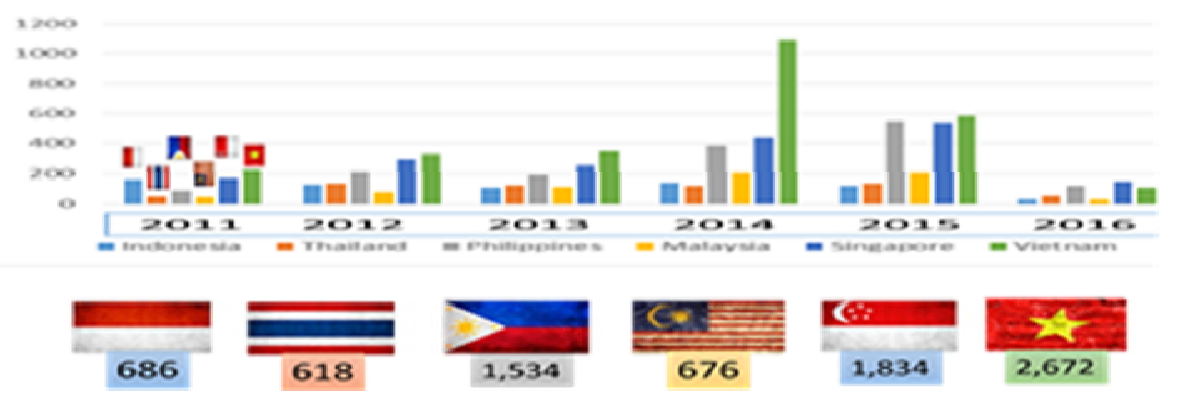

Fig. 2 South China Sea articles, select Asean newspaper, 2011-2016

The results of the coding on the frames found within the Jakarta Post's articles show a bifurcated result, Figure 3. The frames of 'Conflict' and 'Responsibility' were the two that featured most prominently in the pages of the Post. The conflict frame tended to reflect conflict and disagreement among principal actors. The 'Responsibility' frame is defined as "a way of attributing responsibility for [a] cause or solution to either the government or to an individual or group" [26]. Coding was done on all 52 articles by both coders with a final agreement figure of $86 \%$. In these articles, there was a slight yet noticeable tendency to attribute responsibility to China for increasing tensions in the region. It should be noted, that during the time period under investigation, Indonesia caught a Chinese fishing boat in its territorial waters off of the Natuna islands. 


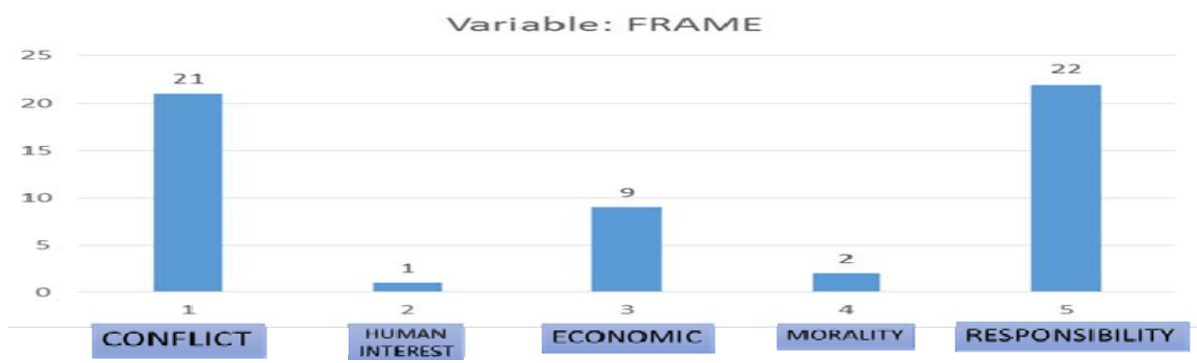

Fig. 3 Dominant Frame, Jakarta, post April 2015 to April 2016, N=52

In the study's collected articles, the tendency was for negative words to appear in and around the sentences that mentioned the country of 'China,' Figure 4. This happened more often than was the case for neutral or positive word pairings. The reverse was true for 'Asean' and 'the United States', where neutral and positive word pairings were noticed. It is clear, though that China and Asean received far greater mentions in the coverage.
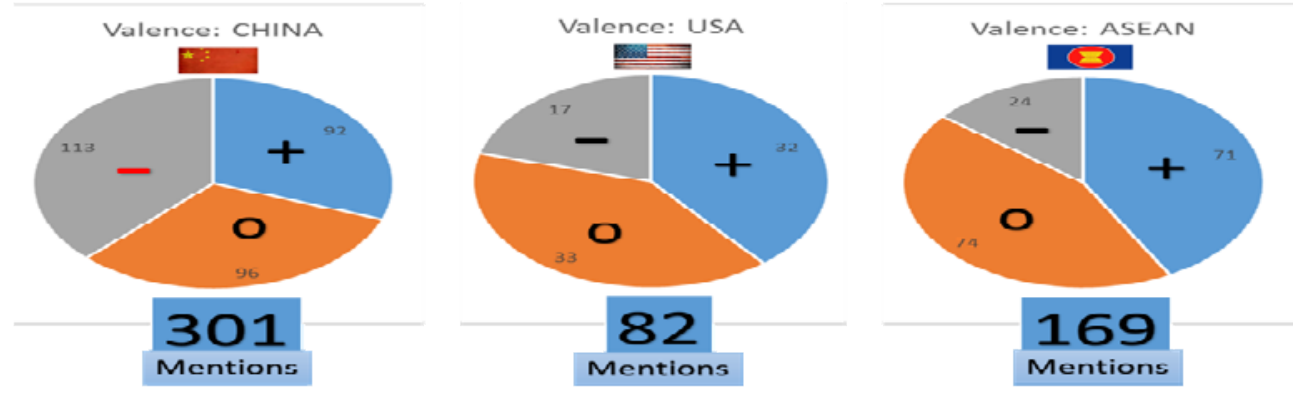

Fig. 4 Variable : Valence. Jakarta post, April 2015 to April 2016, N=52

\section{Discussion and conclusion}

There is no doubt that the issues surrounding the South China Sea are gaining more and more attention from scholars and journalists the world over. The study found that the term 'South China Sea' is the dominant title used in Southeast Asia's regional English-language newspapers - with the exception of Vietnam's press, where 'East Sea' is preferred. One might expect that the Philippine papers would follow in the same footsteps by preferring to use the term 'West Philippine Sea.' Use of certain labels and terms may have a 'branding' effect and can lead to a 'spiral of framing' in an intermedia agenda-setting way where the use of one term over another may come to be preferred.

The Asean newspapers clearly afford topics surrounding this body of water a lot of coverage. Interestingly, Singapore's newspaper had the most amount of coverage (next to Vietnam), though it does not have a territorial dispute with China on the matter. There may be a few reasons for this. Singapore may see itself, arguably true, in a unique position to comment on this matter. Singapore settled a court case with Malaysia over the territory of Pedra Branca (International Court of Justice in 2008). The case between the Philippines and China is unlikely to settle issues as succinctly.

Following this preliminary study, more research will be necessary to dig deeper into the specifics of this coverage - to uncover the precise nature of all of the relevant coverage. The articles have been collected from the Asean papers, and the task of coding is expected to proceed. The degree to which the topic receives attention does tend to match closely specific cases that occur with regards to this body of water. That is to say, when the 
Philippines brought the international court case, when a summit has been held, or when the Vietnamese protested the Chinese oil rig placement - we see a corresponding increase in coverage of the matter. In recent years, there seems to be a discernable increase in activity in the South China Sea region.

As is typical for the news media, 'Conflict' (the conflict and disagreement that exists in or around an issue) was shown to be a major theme in the coverage, but that was also matched by the frame of 'Responsibility.' It will be interesting to examine and see if this holds true for other years, and for other papers in the region. The current study represented a preliminary effort to investigate the South China Sea issue from the perspective of the media (newspaper coverage). Again, further investigation into the coverage is warranted particularly when the link between media coverage, soft power, and public relations is known to impact on media audiences and potentially, public policy.

\section{References}

1. M.J. Valencia, South China Sea: Present and potential coastal area resource use conflicts. Ocean Management, 5, 1-38. (1979).

2. M.S. Samuels, Contest for the South China Sea. New York: Methuen. (1982).

3. C.K. Lo, China's Policy towards territorial disputes: the case of the South China Sea Islands. New York: Routledge. (2003).

4. China to secure. China to secure 'de facto' control of S. China Sea: US admiral. Agence France Presse. (2016, February 26 ). Retrieved using the Factiva database.

5. R. Murphy, J. Marx, Obama's ASEAN summit ends with business, security pact. The Desert Sun. (2016, February 16). Retrieved from: http://www.desertsun.com/story /news/2016/02/16/sunnylands-obama-Asean-statement/80457706/

6. H.Y. Tan, Tribunal ruling on South China Sea is binding, stresses Obama. The Straits Times. (2016, September 9). Retrieved from: http://www.straitstimes.com/asia/tribunal-ruling-on-s-china-sea-is-binding-stressesobama

7. R.D. Kaplan, Asia's Cauldron: The South China Sea and the End of a Stable Pacific. New York: Random House. (2015).

8. B. Hayton, The South China Sea: The struggle for power in Asia. Yale University Press. (2014).

9. E. Goffman, Frame Analysis: An Essay on the Organization of Experience. New York: Harper \& Row. (1974).

10. T. Gitlin, The whole world is watching. Berkley, CA: University of California Press. (1980).

11. R.M. Entman, Framing: Toward clarification of a fractured paradigm. J. Commun 43(4), 51-58. (1993).

12. J.W. Tankard, The empirical approach to the study of media framing. In D. Reese, O. Gandy, and A. Grant (Eds.), Framing public life: Perspectives on media and our understanding of the social world, 95-106. New York: Routledge. (2001).

13. D.H. Weaver, Thoughts on agenda setting, framing, and priming. J.Commun, 57(1), 142-147. (2007).

14. D.A. Scheufele, Framing as a theory of media effects. J. Commun 49(1), 103-122. (1999).

15. P.J. Shoemaker, S.D. Reese, Mediating the message, $3^{\text {rd }}$ ed. Thousand Oaks, CA: Sage. (2013).

16. S.D. Reese, The framing project: A bridging model for media research revisited. J. Commun 57(1), 148-154. (2007). 
17. S. Yousaf, Representations of Pakistan: A framing analysis of coverage in the U.S. and Chinese news media surrounding Operation Zarb-e-Azb.J Commun, 9, 3042-3064. (2015).

18. C.E. Carroll, M. McCombs, Agenda-setting effects of business news on the public's images and opinions about major corporations. Corporate Reputation Review, 6(1), 3646. (2003).

19. J. Kim, S. Yang, Effects of government public relations on international news coverage. Public Relations Review, 34(1), 51-53. (2008).

20. S. Lee, An analysis of other countries' international public relations in the US. Public Relations Review, 32(2), 97-103. (2006).

21. J. Wang, Managing national reputation and international relations in the global era: Public diplomacy revisited. Public Relations Review, 32(2), 91-96 (2006).

22. P. Brewer, J. Graf, L. Wilnat, 'Priming or Framing: Media Influence on Attitudes toward Foreign Countries', J.Commun 65(6), 493-508 (2003)

23. E. Regullano, Filipinos Depicted in American Culture. e-Research: AJUR, 3(1), 6. (2014).

24. W. Lippmann, Public opinion. Transaction Publishers. (1946).

25. C. Naveh, The role of the media in foreign policy decision-making: A theoretical framework. Conflict and Communication online, 1(2), 1-14. (2002).

26. P. Valkenburg, H. Semetko, Framing European politics: a content analysis of press and television news. J.Commun, 50(2), 93-109. (2000).

27. M. Sparkes, Revealed: how Google moves international borders. The Telegraph. (2014, June 24). Retrieved from: http://www.telegraph.co.uk/technology/google/10922595/ Revealed-how-Googlemoves-international-borders.html

28. Google maps. Google Maps drops Chinese name for disputed area in the South China Sea. South China Morning Post. (2015, July 14). Retrieved from: http://www.scmp.com/news/ china/diplomacy-defence/article/1838609/google-mapsdrops-chinese-name-disputed-area-south

29. U.S., ASEAN warn Beijing. U.S., ASEAN warn Beijing over outrageous actions in S. China Sea. The Yomiuri Shimbun. (2016, February 18). Retrieved from: http://thejapan-news.com/news/article/0002756678

30. H.D. Lasswell, J.Z. Namenwirth, J. Z. The Lasswell value dictionary. New Haven: Yale University Press. (1969).

31. C.E. Osgood, The nature and measurement of meaning. Psychological bulletin, 49(3), 197. (1952).

32. C.E. Osgood, G.J. Suci, P.H. Tannenbaum, The measurement of meaning. Champaign, Illinois: University of Illinois Press. (1957).

33. J. Perlah, China, Vietnam Oil Rig Spat: China Says It 'Will Never Send Military'. International Business Times. (2014, June 13). Retrieved from: http://www.ibtimes.com /china-vietnam-oil-rig-spat-china-says-it-will-never-sendmilitary-1601252 